\title{
Grzegorz Stępniak
}

\section{Trzydzieści ton polskiej, polskiej literatury queerowej}

Dezorientacje: Antologia polskiej literatury queer redakcja Alessandro Amenta, Tomasz Kaliściak i BłażejWarkocki (Warszawa: Wydawnictwo Krytyki Politycznej, 2020)

Niedawno nakładem Wydawnictwa Krytyki Politycznej ukazała się monumentalna i bezprecedensowa na polskim gruncie literacko-naukowym książka - Dezorientacje. Antologia polskiej literatury queer. Alessandro Amenta, Tomasz Kaliściak i Błażej Warkocki opatrzyli tę liczącą ponad dziewięćset stron „księgę polskiego queeru" obszernym wstępem zatytułowanym wymownie: Literatura przewrotna. To określenie odnosi się do wszystkich zebranych w niej tekstów, które - choć 
wyrastają z odmiennych kontekstów historyczno-kulturowych i różnią się między sobą formą i treścią - w mniejszym lub większym stopniu grają z normami seksualnymi i płciowymi. Jak zaznaczają redaktorzy tomu, koncepcja książki z jednej strony wpisuje się w światowy nurt akademicko-kulturowy, który można określić terminem queer, z drugiej zaś - odwołuje się do lokalnej tradycji badań nad literaturą odmieńczą, zapoczątkowanej w latach osiemdziesiątych przez serię antologii Transgresje. Tytuł - Dezorientacje - odsyła do szeroko pojętej orientacji seksualnej autorów, bohaterów czy podmiotów lirycznych. Nie idzie tu jednak o proste i deklaratywne określenia homoseksualności, a raczej o ukazanie skomplikowanej, wielopoziomowej i zmiennej w czasie sieci identyfikacji oraz tożsamościowych gier. Trudno, żeby było inaczej - wszak otwierający antologię wiersz Franciszka Karpińskiego Do przyjaciela został opublikowany po raz pierwszy w 1780 roku, kiedy nie istniał język, który obecnie służy określeniu pożądania osoby tej samej płci. Jak przekonuje Michel Foucault, którego duch unosi się nad antologią, nasze rozumienie seksualności i homoseksualności jest wynalazkiem końca XIX wieku'. Włączenie do antologii tekstu dawniejszego to zatem gest wymowny, ale też arbitralny i poniekąd interpretacyjny - umieszcza go bowiem w kontekście współczesnego myślenia o płci i seksualności.

Dezorientacjom matronuje amerykańska badaczka queer Eve Kosofsky Sedgwick, która w swoich pracach na nowo odczytywała klasyczne teksty literackie, wskazując na ukryte wątki i motywy homoseksualne. Jej kanoniczne już dzieło - wydana w 1990 Epistemology of the Closet - to nie tylko manifest podważający binarne opozycje seksualne, płciowe i estetyczne, ale też interpretacyjny kompas pokazujący, jak dotrzeć do zakamuflowanych homoerotycznych treści. Sedgwick podkreśla, że postrzeganie ludzkiej seksualności podlega historycznym zmianom, i krytykuje uniwersalistyczne aksjomaty, obnażając wynikające z nich ideologiczne niebezpieczeństwa, przede wszystkim tendencje asymilacyjne oraz wzmacnianie systemowej homofobii².

Redaktorzy tomu Dezorientacje są świadomi przemian w rozumieniu i wykorzystywaniu metodologii queerowej. Sięgają po pojęcie „literatury mniejszej” Gillesa Deleuze’a i Félixa Guattariego, dodając, że zebrane w antologii teksty są bez wątpienia mniejszościowe, ale zarazem konstytuują widzialność w ramach oficjalnego języka3. Zwracają przy tym uwagę na kwestie, o których często zapomina się w polskim kontekście: polityka queer jest zmienna w czasie, ale pozostaje antyasymilacyjna i antyseparatystyczna i zdecydowanie opowiada się przeciw normalizującym i normatywnym dyskursom. Bardzo blisko jest im więc

\footnotetext{
1 Zob. Michel Foucault, Historia seksualności, t. 1-3, tłum. Bogdan Banasiak, Tadeusz Komendant i Krzysztof Matuszewski (Gdańsk: słowo/obraz terytoria, 2010).

2 Zob. Eve Kosofsky Sedgwick, Epistemology of the Closet (Berkley: University of California Press, 199o).

3 Alessandro Amenta, Tomasz Kaliściak i Błażej Warkocki, red., Dezorientacje: Antologia polskiej literatury queer (Warszawa: Wydawnictwo Krytyki Politycznej, 2020), 27-29. Kolejne cytaty lokalizowane są w tekście głównym w nawiasach.
} 
do rozumienia queeru w taki sposób, jaki na początku lat dziewięćdziesiątych zaproponowała jego nestorka - Judith Butler, która w eseju Critically Queer wyraża programową nieufność do stabilnych i jednoznacznych terminów, procesów czy tworów naukowych, w tym także do samego terminu queer. Badaczka zaznacza:

Trzeba będzie zaakceptować przygodność tego pojęcia: pozwolić, by zostało przezwyciężone przez tych, którzy są przez nie wykluczani, chociaż słusznie oczekują, że będą przez nie reprezentowani; pozwolić, by nabrało znaczeń nieprzeczuwanych jeszcze przez młode pokolenie, którego polityczny słownik może nieść zupełnie inne rodzaje zaangażowania ${ }^{4}$.

Szczególnie cieszy fakt, że w Polsce - kraju konserwatywnym, patriarchalnym i katolickim - ukazuje się antologia, której redaktorzy podejmują się „pracy u podstaw", tworząc pierwszy tak szeroko zakrojony tom zbierający rodzimą literaturę queerową. Co więcej, sięgają również po teksty zapomniane, dawniejsze i nieoczywiste, często odczytując je - w duchu Sedgwick - wbrew ustalonym interpretacjom, wskazując na ich homoerotyczny potencjał.

Książka została podzielona na cztery części: Sercem bliscy (do 1918), Sztuka przewrotna (1918-1945), Nawet milczenie / Miało być przemilczane (1945-1989) oraz Koniec barw ochronnych (po 1989). Ich tytuły odwołują się do sytuacji mniejszości seksualnych w danym okresie historycznym w Polsce, a zarazem wyznaczają perspektywę interpretacyjną, z której możemy spoglądać na twórczość mniejszościową. W pierwszej części znalazły się fragmenty dzieł narodowych wieszczów i uznanych autorów romantycznych, pozytywistycznych i młodopolskich, na szczególną uwage zasługują jednak teksty Narcyzy Żmichowskiej i Piotra Odmieńca Własta/Marii Komornickiej. W opublikowanych w tomie fragmentach Białej Róży Żmichowskiej motywy greckie i safickie wyraźnie wskazują na temat przewodni - romans między dwiema kobietami, Panną Kazimierą i Panną Augustą (tytułową Białą Różą). Powieść ta jest ważna dla polskiej literatury mniejszościowej również z tego względu, że odwołują się do niej inni pisarze, od Tadeusza Boya-Żeleńskiego, przez Tadeusza Różewicza, aż po Izabelę Morską (Filipiak) i Renatę Lis (teksty wszystkich wymienionych również znalazły się w Dezorientacjach).

Twórczość Marii Komornickiej, która w wieku trzydziestu jeden lat dokonała płciowej transformacji i przyjęła wiele mówiące imię - Piotr Odmieniec Włast, reprezentowana jest w antologii przez powieść Biesy z 1902. Tworząc figurę niedopasowanego/niedopasowanej genderowo i diagnozującego/diagnozującej się jako byt „źle urodzony” bohatera/bohaterki, Komornicka/Włast staje się prekursorką/ prekursorem rodzimej literatury transgenderowej. Właśnie ona/on jest także

4 Judith Butler, "Critically Queer", w: Bodies That Matter: On the Discursive Limits of Sex (New York: Routledge, 1993), 230; tłumaczenie G.S. 
główną postacią dramatu Izabeli Morskiej (Filipiak) Księga Em z 2005, którego fragment znalazł się w ostatniej części Dezorientacji. W opublikowanej w antologii scenie ostrej dyskusji Własta z Politykiem (wzorowanym na Romanie Dmowskim) o tym, co stanowi i wyznacza polskość, Filipiak obnaża anachroniczność genderowych kategorii silnie obecnych w rodzimych dyskursach patriotycznych:

PоLIT Yк: Głos obcej rasy kobiecej miałem na myśli. Wie pan, o czym mówię? Antagonizm płci, który opisał już w starożytności Platon - znana teoria nieprzystających do siebie męskich i żeńskich połówek - stał się w naszej epoce tematem filozoficznych i socjologicznych dociekań (641).

Polityk faworyzuje męskość, tłumacząc Włastowi, że pod męską postacią może zostać „królem Polski”. Ironiczne podkreślenie seksizmu narodowego języka pomaga przy okazji uwypuklić genderowy paradoks - w polskim kontekście politycznym transgenderowy mężczyzna znajduje się często w lepszej sytuacji niż cis-genderowa (taka, której płeć biologiczna zgadza się z kulturową) kobieta.

W drugiej części antologii szczególnie interesujące są felietony i recenzje Tadeusza Boya-Żeleńskiego oraz Ireny Krzywickiej. Tekst Przedwiośnie Boya-Żeleńskiego, opublikowany w „Kurierze Porannym” w 1927, stanowi odważny głos w toczącej się wówczas debacie o nowym projekcie kodeksu karnego, który ostatecznie wszedł w życie pięć lat później i nie zawierał paragrafów penalizujących dobrowolne stosunki homoseksualne. Karał wprawdzie za homoseksualną prostytucję, ale i tak stanowił jedno z najnowocześniejszych i najbardziej liberalnych rozwiązań prawnych w Europie. Felieton Boya, postulujący wolność obyczajową i większą otwartość wobec mniejszości seksualnych, brzmi szczególnie nowocześnie bez mała sto lat później, kiedy nagonki na społeczność LGBTQIA są w Polsce na porządku dziennym, a w kraju powstają „strefy wolne od LGBT". Jednocześnie poszerza tematykę antologii o sferę prawno-legislacyjną - istotną, jak twierdzi Dean Spade, dla konstytuowania się mniejszościowych tożsamości. Co prawda Spade pisze głównie o transgenderowych społecznościach, określając ich członków mianem "nielegalnych bytów”, ale jego rozważania można śmiało odnieść do prawno-administracyjnego aspektu tożsamości homoseksualnych, o którym wspomina Boy.

Z kolei recenzje powieści Colette i Radclyffe Hall autorstwa Ireny Krzywickiej, pochodzące z przełomu lat dwudziestych i trzydziestych ubiegłego wieku, poświadczają swobodną wędrówkę marginalizowanych tematów i literatury mniejszościowej pomiędzy Zachodem a Polską. W Tej drugiej Colette opisuje kobiecy trójkąt miłosny, a Krzywicka przenikliwie zauważa, że bohaterkom udaje się przechytrzyć

5 Por. Dean Spade, Normal Life: Administrative Violence, Critical Trans Politics, and the Limits of Law (Durham: Duke University Press, 2011). 
mieszczańskie konwenanse i opresyjne normy obyczajowe, by stworzyć związek pod pozorem relacji z mężczyzną. Natomiast pisząc o Studni samotności - lesbijskiej powieści Hall, która ukazała się w 1928, a w polskim tłumaczeniu już pięć lat później - Krzywicka koncentruje się na rewolucyjnym traktowaniu kobiecej seksualności i pożądania. Zwraca uwagę na szczególny typ lesbijskiej tożsamości (obecnie określany jako butch, czyli męski) i pozytywnie ocenia szczerość, z jaką główny bohater/bohaterka Stephen podąża za swoimi pragnieniami. Krzywicka docenia również otwartość autorki/autora książki - Hall nie do końca identyfikuje się jako kobieta, odrzuca więc schematy, by żyć w zgodzie z własnymi przekonaniami i tożsamościowymi potrzebami. Co zaskakujące, Krzywicka w krótkim tekście proponuje lekturę powieści Hall podobną do interpretacji Jacka Halberstama opublikowanej bez mała sześć dekad później w kanonicznej dla queer studies książce o kobiecej męskoścí. Podobnie jak Halberstam, rozpatruje tę kwestię na dwóch planach: stricte powieściowym i biograficznym, dotyczącym życia Hall.

W trzeciej części Dezorientacji uwagę zwraca powieść Anny Kowalskiej Safona Z 1959, przedstawiająca historię nieszczęśliwej miłości greckiej poetki zakochanej w dużo młodszym Faonie oraz trudną relację z uczennicą Megarą. Jak podpowiadają redaktorzy tomu, utwór można czytać w kluczu biograficznym, przez pryzmat relacji, jaka łączyła Kowalską z Marią Dąbrowską, a równocześnie należałoby wpisać ją w nurt literatury safickiej, eksplorującej kobiecą miłość w relacji mistrzyni-uczennica. Bodaj najciekawiej wybrzmiewa w tej części antologii znany fragment Białego małżeństwa Tadeusza Różewicza. Poeta i dramatopisarz drwi tu z zasad drobnomieszczańskiego świata, osadzając akcję w modelowym młodopolskim dworku. Para pozornie niewinnych dziewcząt, Bianka i Paulina, rozpoznaje swoje psychologiczne, cielesne i kulturowe możliwości, obserwując życie codzienne członków rodziny i poczynania dziadka-erotomana w kontekście Życia i obyczajów zwierząt. Bohaterki przekonują się na własnej skórze o arbitralności i ambiwalencji płci oraz modeli pragnienia i pożądania. Tym silniej i bardziej wywrotowo wybrzmiewa słynna, finałowa scena rozmowy między Bianką a Beniaminem (imiona bohaterów są zresztą odwołaniem do Poganki Żmichowskiej i idei „posiestrzenia” właściwego dla pisarki, a odnoszącego się zarówno do sfery społecznej, jak i seksualnej):

Bianka nie odzywa się. Patrzy w lustro. Wyciaga ręce do ognia, jakby chciała ogrzać dłonie. Patrzy w ogień (około dziesięć sekund). Nieruchoma. Potem powoli ściaga dlugie rękawiczki i wrzuca je do kominka. Zdejmuje kapelusz, wrzuca do kominka. [...] Stoi w lustrze naga, z rozpuszczonymi włosami. Po chwili bierze duże nożyce i obcina sobie włosy krótko do skóry, nierówno. Odkłada nożyce. Zakrywa piersi rękami i mówi do swojego odbicia w lustrze: „jestem”, po chwili krzyczy: „jestem gotowa”. Do sypialni

6 Zob. Jack Halberstam, Female Masculinity (Durham: Duke University Press, 1998). 
wchodzi ubrany wizytowo (gotowy do wyjścia) Beniamin. Zatrzymuje się. Bianka odwraca się powoli.

BIANKA: Jestem (robi krok w stronę Beniamina), jestem... (opuszcza ramiona)... twoim (szeptem) bratem... (490-491).

Różewicz ukazuje w teatralnym "tu i teraz" genderową przemianę bohaterki/bohatera, która dokonuje się na oczach widzów, na zasadzie powtarzanych w czasie, jak podpowiada Butler, aktów performatywnych. A równocześnie kpi z najbardziej fundamentalnych heteronormatywnych instytucji: zamiast ślubu i małżeństwa proponuje subwersywną scenę zaślubin Bianki z samą sobą i własną męską tożsamością, by przekształcić ją ostatecznie w prześmiewczy i genderowo ambiwalentny rytuał braterski. I to wszystko prawie dwie dekady przed rozpoczęciem naukowych dyskusji o performatywności płci.

Czwarta część antologii - poświęcona najnowszej polskiej literaturze - jest najbardziej obszerna i różnorodna formalnie. Pośród wielu tekstów otwarcie homoseksualnych autorów i utworów dotyczących problemów LGBTQIA (coming outy, miłość, romanse, relacje między osobami tej samej płci) zwracają uwagę dwa fragmenty dramatyczne twórców, którzy zwykle zajmują się nieco inną tematyką. Scena ze sztuki Tęczowa Trybuna 2012 Pawła Demirskiego rozgrywa się między gejowską parą, Nauczycielem i Kelnerem, reprezentującymi, jak często u Demirskiego bywa, dwa przeciwstawne światy. Sztuka opowiada historię gejowskiego fanklubu piłki nożnej i starań o utworzenie osobnego sektora dla gejów na trybunach stadionów mistrzostw Euro 2012. Strzępka i Demirski utrzymywali, że grupa homoseksualnych fanów piłki nożnej, o jakiej opowiadają, jest autentyczna, a przedstawienie zainspirowało wiele dyskusji na temat tolerancji, systemowej homofobii środowisk sportowych i rzekomo modelowo heteroseksualnej polskości. Kiedy jednak teraz, po upływie niemal dekady od premiery, uważniej wczytać się w zamieszczoną w Dezorientacjach scenę, okazuje się, że poza prześmiewczym obnażeniem klasowości i jej związków z seksualnością czy kilkoma celnymi obserwacjami dotyczącymi tak zwanej homonormatywności społeczności gejowskich ${ }^{7}$ jej wydźwięk jest nieco problematyczny. Demirski posługuje się bowiem uproszczonymi wyobrażeniami na temat wielkomiejskiej homoseksualności, którą w dodatku każe określać swoim bohaterom jako „pedalstwo”. Wyśmiewana przez Kelnera kawa latte i francuska bagietka są, w zamierzeniu autora, symbolicznymi emblematami homomieszczaństwa, niepokoi jednak stereotypowy charakter obrazu obu mężczyzn jako histerycznych gejów.

7 Chodzi o kultywowanie norm i zwyczajów większości, na czele z prawem do zawierania małżeństw przez przedstawicieli tej samej płci, które w queerowym, antyasymilacyjnym duchu krytykowane jest przez wielu amerykańskich badaczy. Zob. np. Lisa Duggan, Twilight of Equality? Neoliberalism, Cultural Politics, and the Attack on Democracy (Boston: Beacon Press, 2003). 
Dezorientacje zamyka fragment sztuki Jolanty Janiczak O mężnym Pietrku i sierotce Marysi. Bajka dla dorosłych, której premiera w reżyserii Wiktora Rubina odbyła się w 2018 roku w Teatrze Polskim w Poznaniu. Tekst opowiada o długoletnim lesbijskim związku Marii Konopnickiej z malarką Marią Dulębianką, którą pisarka nazywała pieszczotliwie Pietrkiem. Janiczak opiera się tu częściowo na dostępnych materiałach źródłowych, ale przede wszystkim dokonuje szeroko zakrojonej rewizji przeszłości, reinterpretując w wyzwoleńczym i emancypacyjnym duchu losy polskiej pisarki i jej homoseksualny związek wymazywany z kart historii. Postacie historyczne - na przykład Maksymilian Gumpłowicz, który rzekomo z powodu nieszczęśliwej miłości do Konopnickiej popełnił samobójstwo - sąsiadują z postaciami emblematycznymi dla kultury lesbijskiej początku xx wieku, na czele $\mathrm{z}$ autorką/autorem Studni samotności Radclyffe Hall oraz jej partnerką Mabel Batten. W przytoczonej w tomie scenie Hall i Batten dopingują Konopnicką i Dulębiankę do działania oraz symbolicznej emancypacji wszystkich kobiet z patriarchalnego, homofobicznego systemu. Autorka Roty wzywa kobiety do solidarności i upomnienia się o swoje prawa:

KONOPNICKA: Gdzie jesteście ciotki, siostry, chłopki, służące, zakonnice, mieszczki, robotnice, inteligentki, profesorki, akuszerki, hafciarki, tkaczki, salowe, kelnerki, śpiewaczki, aktorki pogardzane i uwielbiane zarazem, sprzątaczki, pracownice socjalne, policjantki. Prostytutki, które swoją obecnością podgryzacie fasadę uczciwego życia rodzinnego uprzywilejowanych. Nie wstydźmy się! Nadszedł nasz czas! Mamy prawo do swojej ekspresji! Mamy prawo żyć, nie realizować szablony! Koniec z realizowaniem czyichś oczekiwań! Koniec barw ochronnych! Przynoście fragmenty, migawki, okruszki, zdania, zdjęcia, pocałunki, pamiątki do naszego właśnie w tym momencie powstającego w tym mieście Archiwum im. Marii Konopnickiej i Marii Dulębianki (892-893).

Konopnicka w interpretacji Janiczak znosi podziały klasowe pomiędzy kobietami, namawiając je do głośnego mówienia własnym głosem. Po tej programowej przemowie w finale Dulębianka informuje, że zgodnie z ich marzeniami Sejm RP uchwalił ustawę o związkach partnerskich. Scena przeradza się więc w utopijną i queerową - zarówno treściowo, jak i formalnie - wizję teraźniejszości i re-wizję przeszłości, która otwiera nadzieję na przyszłość. Wszak, jak podkreśla José Esteban Muñoz:

QUEERowośCI NIE MA jeszcze tutaj. Queerowość to ideał. Innymi słowy, nie jesteśmy jeszcze queer. Może nigdy nie otrzemy się o queerowość, ale jesteśmy w stanie ją poczuć jako ciepłe światło horyzontu wypełnionego potencjalnością

8 José Esteban Muñoz, Cruising Utopia: The Then and There of Queer Futurity (New York: New York University Press, 2009), 1. Wybrane fragmenty książki Muñoza zostały przełożone na języki polski przez Michała Abla Pelczara i opublikowane w: Agnieszka Gajewska (red.), Teorie wywrotowe: Antologia przekładów (Poznań: Wydawnictwo Poznańskie, 2012), jednak korzystam z własnego tłumaczenia, ze względu na fragmentaryczność dostępnego po polsku przekładu. 
Zamknięcie antologii polskiej literatury queer właśnie tą sceną to trafna decyzja. Nic nie jest przecież w Polsce tak konieczne, jak odrzucenie opresyjnej teraźniejszości i wiara w majaczącą na horyzoncie wizję bardziej otwartego, queerowego świata.

Skomentowałem wszystkie zamieszczone w Dezorientacjach fragmenty tekstów dramatycznych, żeby pokazać jak niewielki procent polskiej queerowej literatury stanowią $\mathrm{w}$ antologii sztuki teatralne. Nie jest to oczywiście zarzut wobec redaktorów tomu, choć bez trudu wskazać można więcej utworów dramatycznych opowiadających o przedstawicielach społeczności LGBTQIA albo o (homo)seksualności. Do głowy przychodzą mi chociażby sztuki Ingmara Villqista, Przemysława Wojcieszka, Julii Holewińskiej, Macieja Kowalewskiego oraz niedoceniony, na wskroś queerowy, wykraczający poza tematykę seksualności dramat Marii Pawlikowskiej-Jasnorzewskiej - Baba-Dziwo. Takich tekstów można wymienić znacznie więcej, można także przeczytać klasykę polskiego dramatu w queerowej perspektywie.

Doceniam inicjatywę Alessandro Amenty, Tomasza Kaliściaka i Błażeja Warkockiego, zwłaszcza że ułożona przez nich antologia jest w Polsce niezwykle potrzebna. Sądzę jednak, że wbrew deklaracjom zawartym we wstępie kategoria queeru została w niej uproszczona. Owszem, redaktorzy zadbali, żeby w tomie znalazło się jak najwięcej autorów-kobiet i autorów-transgenderowych, chociaż polska kultura i literatura są w większości męskocentryczne. Queer został tu jednak sprowadzony do kwestii związanych z modelami (homo)seksualności i ich związków z gender. Tymczasem ta decyzja jest nie tylko anachroniczna, ale też sprzeczna z ideą queeru, najbardziej pojemnej i inspirującej ze współczesnych humanistycznych metodologii. Queer obejmuje przecież nie tylko to, co homoseksualne, ale zgodnie ze swoim pierwszym znaczeniem również to, co dziwaczne, nienormatywne, zaburzające status quo. Wystarczy sięgnąć po publikacje queer studies z ostatniej dekady, na czele z wydaną również w Polsce książką Jacka Halberstama Przedziwna sztuka porażki ${ }^{9}$, żeby przekonać się, że seksualność jest w nich jedynie punktem wyjścia, a znacznie bardziej interesujące okazują się analizy rozmaitych nienormatywnych i spychanych na kulturowe i społeczne marginesy zjawisk, w rodzaju zapominania, przegrywania, alternatywnych struktur rodzinnych czy społecznych. Do zawartości Dezorientacji bardziej pasowałby podtytuł „antologia polskiej literatury LGBTQIA”, ponieważ zawężanie queeru do kwestii (homo)seksualności to praktyka typowa choćby dla studiów gejowsko-lesbijskich.

Redaktorzy Dezorientacji zdają się nie pamiętać także o tym, że ustanawianie kanonu, jak pokazuje feministyczna historyczka sztuki Griselda Pollock ${ }^{10}$, to

9 Zob. Jack Halberstam, Przedziwna sztuka porażki, tłum. Mikołaj Denderski (Warszawa:Wydawnictwo Krytyki Politycznej, 2018).

10 Por. Griselda Pollock, Differencing the Canon: Feminism and the Writing of Art Histories (London: Routledge, 1999). 
zadanie karkołomne i pełne ideologicznych pułapek. Wpisywanie w istniejący kanon nowych, pomijanych dotąd dzieł jedynie umacnia jego struktury, a tworzenie nowych kanonów utwierdza hegemoniczny i uniwersalistyczny system gromadzenia i dystrybuowania wiedzy i władzy, który raczej należałoby dekonstruować. Oczywiście, w Polsce praca, jaką wykonali Amenta, Kaliściak i Warkocki, jest niezbędna, by zmienić pozycję literatury mniejszościowej. Warto jednak zaznaczyć, że tworzenie antologii - przeglądu ułożonego chronologicznie, według zasad właściwych dla kanonu - kłóci się z ideowymi założeniami antylogicznego, antystrukturalnego i antykanonicznego queeru.

W trakcie lektury przypomniał mi się popularny w Polsce w latach dziewięćdziesiątych ubiegłego wieku telewizyjny program 30 ton - lista, lista przebojów. Jego konstrukcja - a prezentowano w nim trzydziestosekudowe fragmenty najczęściej granych wówczas hitów - przypomina mi nieco strukturę Dezorientacji. Umieszczone $\mathrm{w}$ antologii fragmenty tekstów najbardziej reprezentatywnych, zdaniem redaktorów tomu, dla polskiej literatury queerowej, podobnie jak teledyski z 30 ton, mają rozbudzić apetyt odbiorców i stymulować ich dalsze, prowadzone na własną rękę poszukiwania i lektury. Miejmy zatem nadzieję, że dzięki Dezorientacjom polski horyzont literacko-kulturowy rozświetli, jak chciałby Muñoz, queer.

\section{Bibliografia}

Amenta, Alessandro, Tomasz Kaliściak i Błażej Warkocki, red. Dezorientacje: Antologia polskiej literatury queer. Warszawa: Wydawnictwo Krytyki Politycznej, 2020.

Butler, Judith. Bodies That Matter: On the Discursive Limits of Sex. New York: Routledge, 1993.

Duggan, Lisa. Twilight of Equality? Neoliberalism, Cultural Politics, and the Attack on Democracy. Boston: Beacon Press, 2003.

Foucault, Michel. Historia seksualności. T. 1-3. Tłumaczenie Bogdan Banasiak, Tadeusz Komendant i Krzysztof Matuszewski. Gdańsk: słowo/obraz terytoria, 2010.

Halberstam, Jack. Female Masculinity. Durham: Duke University Press, 1998.

Halberstam, Jack. Przedziwna sztuka porażki. Tłumaczenie Mikołaj Denderski. Warszawa: Wydawnictwo Krytyki Politycznej, 2018.

Muñoz, José Esteban. Cruising Utopia: The Then and There of Queer Futurity. New York: New York University Press, 2009.

Pollock, Griselda. Differencing the Canon: Feminism and the Writing of Art Histories. London: Routledge, 1999.

Sedgwick, Eve Kosofsky. Epistemology of the Closet. Berkley: University of California Press, 1990.

Spade, Dean. Normal Life: Administrative Violence, Critical Trans Politics, and the Limits of Law. Durham: Duke University Press, 2011. 


\section{Abstrakt}

\section{Trzydzieści ton polskiej, polskiej literatury queerowej}

Artykuł jest recenzją książki Dezorientacje: Antologia polskiej literatury queer (Warszawa 2020). Autor omawia ideowe założenia tomu oraz jego zawartość, komentując zwłaszcza wybór fragmentów tekstów teatralnych. Zwraca uwagę na nieco anachroniczne wykorzystanie metodologii queer studies, zawężające ją do analizy modeli (homo)seksualności. Doceniając edytorski trud redaktorów i akcentując potrzebę tego typu inicjatyw w polskiej kulturze, proponuje drobne przesunięcia w podejściu do literatury mniejszościowej, które mogłyby pomóc zdekonstruować tradycyjne sposoby ustanawiania historii literatury i kultury.

\section{Słowa kluczowe}

tożsamość, queer, seksualność, nienormatywność, historia literatury

\section{Abstract}

\section{Thirty Tons of Polish, Polish Queer Literature}

This article is a review of the book Dezorientacje: Antologia polskiej literatury queer [Disorientations: An Anthology of Polish Queer Literature] (Warsaw 2020). The author discusses the ideological premises of the volume and presents its contents, commenting in particular on the selection of excerpts from theater texts. He points out that the methodology of queer studies is used here in a somewhat anachronistic way, narrowed down to the analysis of models of (homo)sexuality. Appreciating the editors' efforts and emphasizing the need for such initiatives in Polish culture, he suggests minor shifts in the approach to minority literature, which could help deconstruct the traditional ways of establishing the history of literature and culture.

\section{Keywords}

identity, queer, sexuality, non-normativity, history of literature

\section{GRZEGORZ STĘPNIAK}

absolwent wiedzy o teatrze i dramatologii uj, doktor nauk humanistycznych. Studiował w Department of Theatre Arts University of Pittsburgh, w School of Theatre, Film and Television UCLA oraz w American and Ethnicity Studies Department, University of Southern California, pod opieką Judith „Jacka” Halberstam. Jego zainteresowania naukowe obejmują gender i queer studies, studia nad rasą oraz amerykański performans, film, teatr i telewizję. 